University of Nebraska - Lincoln

DigitalCommons@University of Nebraska - Lincoln

\title{
A biofilm enhanced miniature microbial fuel cell using Shewanella oneidensis DSP10 and oxygen reduction cathodes
}

\author{
Justin C. Biffinger \\ US Naval Research Laboratory, justin.biffinger@nrl.navy.mil \\ Jeremy Pietron \\ Naval Research Laboratory \\ Ricky Ray \\ Naval Research Laboratory \\ Brenda J. Little \\ Naval Research Laboratory, blittle@nrlssc.navy.mil \\ Bradley R. Ringeisen \\ Naval Research Laboratory, ringeisen@nrl.navy.mil
}

Follow this and additional works at: https://digitalcommons.unl.edu/usnavyresearch

Part of the Operations Research, Systems Engineering and Industrial Engineering Commons

\footnotetext{
Biffinger, Justin C.; Pietron, Jeremy; Ray, Ricky; Little, Brenda J.; and Ringeisen, Bradley R., "A biofilm enhanced miniature microbial fuel cell using Shewanella oneidensis DSP10 and oxygen reduction cathodes" (2007). U.S. Navy Research. 14.

https://digitalcommons.unl.edu/usnavyresearch/14
}

This Article is brought to you for free and open access by the U.S. Department of Defense at DigitalCommons@University of Nebraska - Lincoln. It has been accepted for inclusion in U.S. Navy Research by an authorized administrator of DigitalCommons@University of Nebraska - Lincoln. 


\title{
A biofilm enhanced miniature microbial fuel cell using Shewanella oneidensis DSP10 and oxygen reduction cathodes
}

\author{
Justin C. Biffinger ${ }^{\mathrm{a}}$, Jeremy Pietron ${ }^{\mathrm{a}}$, Ricky Ray ${ }^{\mathrm{b}}$, Brenda Little ${ }^{\mathrm{b}}$, Bradley R. Ringeisen ${ }^{\mathrm{a}, *}$ \\ ${ }^{a}$ Chemistry Division, Naval Research Laboratory, 4555 Overlook Avenue, SW, Washington, DC 20375, United States \\ b Oceanography Division, Naval Research Laboratory, Building 1009, John C. Stennis Space Center, MS 39529, United States
}

Received 17 May 2006; received in revised form 18 July 2006; accepted 25 July 2006

Available online 30 August 2006

\begin{abstract}
A miniature-microbial fuel cell (mini-MFC, chamber volume: $1.2 \mathrm{~mL}$ ) was used to monitor biofilm development from a pure culture of Shewanella oneidensis DSP10 on graphite felt (GF) under minimal nutrient conditions. ESEM evidence of biofilm formation on GF is supported by substantial power density (per device cross-section) from the mini-MFC when using an acellular minimal media anolyte $\left(1500 \mathrm{~mW} / \mathrm{m}^{2}\right)$. These experiments demonstrate that power density per volume for a biofilm flow reactor MFC should be calculated using the anode chamber volume alone $\left(250 \mathrm{~W} / \mathrm{m}^{3}\right)$, rather than with the full anolyte volume. Two oxygen reduction cathodes (uncoated GF or a Pt/vulcanized carbon coating on GF) were also compared to a cathode using uncoated GF and a $50 \mathrm{mM}$ ferricyanide catholyte solution. The Pt/C-GF (2-4\% Pt by mass) electrodes with liquid cultures of DSP10 produced one order of magnitude larger power density $\left(150 \mathrm{~W} / \mathrm{m}^{3}\right)$ than bare graphite felt $\left(12 \mathrm{~W} / \mathrm{m}^{3}\right)$ in this design. These advances are some of the required modifications to enable the mini-MFC to be used in real-time, long-term environmental power generating situations.
\end{abstract}

(C) 2006 Elsevier B.V. All rights reserved.

Keywords: Microbial fuel cell; Shewanella oneidensis; DSP10; Mini-MFC; Biofilm

\section{Introduction}

Biological fuel cells (enzymatic and microbial) are rapidly gaining acceptance as an alternative energy technology in addition to the more traditional environmental energy sources such as wind, solar, and geothermal power. Microbial fuel cells (MFCs) can be divided into two types based on the mechanism by which the MFC operates (Angenent et al., 2004; Rabaey and Verstraete, 2005; Bullen et al., 2006). One class of MFCs use the primary metabolic products from bacterial respiration (for example, hydrogen production from Escherichia coli K12 with a Pt-coated, conducting polymer protected anode (Schröder et al., 2003)) while the other type of MFC uses metal reducing bacteria (i.e., Geobacter or Shewanella) that donate electrons to the anode directly through outer membrane cytochromes or through the reduction of redox mediators (quinones and quinolines) secreted by the bacteria (Hernandez and Newman, 2001).

\footnotetext{
* Corresponding author. Tel.: +1 202767 0719; fax: +1 2024048119.

E-mail address: Bradley.Ringeisen@nrl.navy.mil (B.R. Ringeisen).
}

MFCs are particularly promising as power sources for long-term underwater or littoral distributed autonomous sensing (DAS) networks since they are able to scavenge nutrients from the environment and regenerate/sustain the active "catalyst" through bacterial division and colonization at the anode. Because of the assumption that the power from these fuel cells will scale directly with electrode size, much of the work with MFCs has focused on designing larger (total MFC volume $>50 \mathrm{~mL}$ ) systems. However, a recent example suggests that power output is more sensitive to diffusion distance to the proton exchange membrane (PEM) rather than the electrode size (Ringeisen et al., 2006). Therefore, we believe that the development of miniature sensors or sensing networks using MFCs with high power densities per volume will be compatible with direct military, homeland security, and even medical applications in a capacity that cannot be approached with larger devices.

An ideal power source for sustained underwater surveillance applications in the water column would have to meet the following requirements. It should function in an aerobic environment (close to the surface to enable RF communication and enhanced oxygen concentrations for the cathode reaction) and provide 
continuous power (scavenging environmental nutrient sources) for long periods of time (1-10 years). Due to low nutrient concentrations and the natural location of the desired metal reducing bacterial populations, most proposed long-term MFCs are limited to seafloor and river bed deployments in order to maintain an anoxic environment for the anodic reaction (sub-sediment) (Reimers et al., 2001; Tender et al., 2002; Lowy et al., 2006). The need for the sensor to surface from and submerge to the anoxic seafloor makes the prospect of achieving wireless RF communication for a sensor network using these sediment-based devices poor.

An inexpensive and non-intrusive sensing network in the water column requires a deployable biosensor device that is small $(<0.1 \mathrm{~m}$ wide). There are two examples of miniature MFCs $(<10 \mathrm{~mL}$ total device volume) in the literature. Lin first reported a device (device cross-section, $1.8 \mathrm{~cm}^{2}$ ) that used twodimensional (2D) microfabricated electrodes with serpentine flow paths that generated power densities of $0.5 \mathrm{~W} / \mathrm{m}^{3}$ with a ferricyanide catholyte (Chiao et al., 2003). Our group reported another type of mini-MFC (device cross-section, $2 \mathrm{~cm}^{2}$ ) incorporating a three-dimensional (3D) low-density graphite felt (GF) electrode using the facultative anaerobe Shewanella oneidensis DSP10. High power densities were measured from this device $\left(3 \mathrm{~W} / \mathrm{m}^{2}\right.$ and $\left.500 \mathrm{~W} / \mathrm{m}^{3}\right)$, comparable to the highest power densities recorded from macroscopic MFCs using a consortia of metal reducing bacteria $\left(3.6 \mathrm{~W} / \mathrm{m}^{2}\right)$ (Rabaey et al., 2003). The mini-MFC power density was also orders of magnitude higher than a macroscopic MFC using a pure culture of Shewanella putrefaciens and an oxygen cathode $\left(5 \times 10^{-3} \mathrm{~mW} / \mathrm{m}^{2}\right.$, true surface area) (Kim et al., 2002). The shorter diffusion lengths and the high surface-area-to-chamber volume ratio of the mini-MFC device increased its power density relative to that achieved with larger devices (Ringeisen et al., 2006). However, one of the limitations of the mini-MFC device, as described, was a patchy biofilm distribution during the operation of the fuel cell. With only limited biofilm growth, assignment of the working volume of the device was based on several reasonable assumptions, and the mechanism of electron transfer was unclear. In addition, the initial mini-MFC experiments used a ferricyanide catholyte making long-term deployment of the device in a natural environment impractical.

A majority of the MFCs reported in the literature use anodes that have biofilms developed on the surface over enrichment periods of up to 3 years (Gil et al., 2003). Bond and Lovley compared the effectiveness of a MFC operating with Geobacter sulfurreducens in a biofilm to a MFC maintained with planktonic cells in culture medium. They found that there was no loss in power for a MFC maintained with planktonic cells compared to a biofilm-coated anode after 5 days, implying that electron transfer occurred directly from the bacteria to the anode surface. Our original work demonstrated patchy biofilm formation under nutrient-rich conditions (Luria-Bertani broth $+30 \mathrm{mM}$ sodium lactate) (Ringeisen et al., 2006). The work described herein will report the formation of biofilms with DSP10 under minimal nutrient conditions, and discuss the issues associated with the extended use of a MFC supported with only a biofilm-enhanced anode (no additional DSP10 culture or reservoir of cells). The power output of the mini-MFC using uncoated GF or platinum on vulcanized carbon-coated $\mathrm{GF}$ is also compared. Inclusion of $\mathrm{Pt}$ renders the cathode much more effective for oxygen reduction, and represents an advance towards adapting our biofilm-enhanced MFC to the environmental conditions where DAS networks are likely to be used.

\section{Materials and methods}

\subsection{Bacterial culture conditions}

The facultative anaerobe $S$. oneidensis (strain DSP10) was used for all experiments. The DSP10 strain was grown aerobically in a $50 \mathrm{~mL}$ Erlenmeyer flask in Luria-Bertani (LB) broth (Difco Laboratories, Detroit, MI). This culture was incubated at $25^{\circ} \mathrm{C}$ for 5 days with shaking at $100 \mathrm{rpm}$. Cell counts ranged from 1 to $5 \times 10^{8}$ cells $/ \mathrm{mL}$ as determined by plating after serial dilution.

\subsection{Fuel cell assembly and operation}

The dimensions and setup for the mini-MFC apparatus were described previously for a $50 \mathrm{mM} \mathrm{K}{ }_{3} \mathrm{Fe}(\mathrm{CN})_{6}$ (Aldrich) catholyte (Ringeisen et al., 2006). All electrodes used in this study were $0.13 \mathrm{~g}$ samples of GF (Electrosynthesis Company, Lancaster, NY; $\left.0.47 \mathrm{~m}^{2} / \mathrm{g}\right)$. Nafion ${ }^{\circledR}-117$ was purchased from the Fuel Cell Store (Boulder, $\mathrm{CO}$ ) and pre-treated sequentially in hot deionized (DI) water, $3 \%$ hydrogen peroxide solution, $1 \mathrm{M}$ sulfuric acid, and DI water again for $1 \mathrm{~h}$. The treated Nafion ${ }^{\circledR}$ was stored in DI water. The oxygen cathodes were either untreated GF electrodes or Pt/C cathodes fabricated by soaking autoclaved $\left(121^{\circ} \mathrm{C}, 20 \mathrm{~min}\right)$ dry $\mathrm{GF}$ electrodes in a solution comprised of $79.6 \% 18 \mathrm{M} \Omega$ water, $0.4 \%$ by volume of a $5 \%$ Nafion binder solution, $20 \%$ isopropanol, and $5 \mathrm{mg}$ of $19.7 \% \mathrm{Pt}$ on vulcanized carbon powder (DeNora North America, Pt on Vulcan XC-72). The platinum suspension was sonicated for 10 min before soaking the electrode. The overall Pt loading on the GF electrode was between 2 and $4 \%$ on a per mass ratio. The Pt/C electrode was dried for at least $24 \mathrm{~h}$. The catholyte for the oxygen cathode was a $100 \mathrm{mM}$ phosphate buffer ( $\mathrm{pH}$ 7.2). Upon consumption of the ferricyanide catholyte (indicated by the color change from yellow to colorless), the cathode chamber was purged of the used solution and a new $100 \mathrm{~mL}$ reservoir of $50 \mathrm{mM}$ ferricyanide was added.

\subsection{Data acquisition}

The voltage across a load was measured by a personal data acquisition device (I/O tech, personal daq/54) every $2 \mathrm{~min}$. The measured voltage was converted to current through Ohm's law (voltage $=$ current $\times$ resistance) and to power using (power $=$ current $\times$ voltage). Flow was driven with peristaltic pumps at flow rates between 1 and $3 \mathrm{~mL} / \mathrm{min}$. Power measurements were performed in triplicate and the average value was used with a standard deviation of $5 \%$ for all data points. 


\subsection{Biofilm formation within the anode chamber}

To stimulate biofilm formation, $50 \mathrm{~mL}$ of $\mathrm{LB}$ inoculated with $3 \mathrm{~mL}$ of a DSP10 culture $\left(1 \times 10^{8}\right.$ cells $\left./ \mathrm{mL}\right)$ was pumped by a peristaltic pump $(2 \mathrm{~mL} / \mathrm{min})$ through the chambers of the MFC apparatus in an incubator set at $25^{\circ} \mathrm{C}$ (with no shaking). After 5 days, planktonic cells were purged from the tubing and MFC apparatus with $50 \mathrm{~mL}$ degassed LB followed by $25 \mathrm{~mL}$ of degassed minimal media (MM, formulation described by Nealson (Myers and Nealson, 1988)) with $10 \mathrm{mM}$ sodium lactate. Degassing routines were completed with nitrogen flow $(0.45 \mu \mathrm{M}$ PTFE membrane filter in line) and the anode was kept under a nitrogen atmosphere during all biofilm measurements. Mini-MFC experiments using planktonic cultures $\left(10^{8}\right.$ cells $/ \mathrm{mL}$ ) effectively scrub oxygen to sub parts per million levels after one minute, creating an anaerobic system without purging with nitrogen. Previous work showed that vigorous bubbling of air through the culture flask was required to achieve appreciable oxygen levels in the anode chamber at high nutrient flow rates through the fuel cell (Ringeisen et al., in press). However, for biofilm experiments the lower cell densities allowed oxygen to diffuse at higher concentrations throughout the anolyte unless the system was purged with nitrogen.

\subsection{Imaging DSP10 biofilms}

Environmental scanning electron microscopy (ESEM) of the GF electrodes was performed at the Naval Research Laboratory, Stennis Space Center, MS. A $5 \mathrm{~mm} \times 5 \mathrm{~mm}$ section was cut from the fuel cell electrode using a sterile scalpel and placed in a sterile falcon tube containing $10 \mathrm{~mL}$ of $4 \%$ cacodylate buffered glutaraldehyde in distilled water. After a minimum $4 \mathrm{~h}$ in the fixative, the sample was removed and washed with $50 \mathrm{~mL}$ of distilled water. After 1-2 min of gentle rinsing, the sub sample was removed and placed in a countersunk stub on the Peltier cooling device inside the ESEM chamber. The samples were kept wet by using the Peltier cooling device maintained at $4{ }^{\circ} \mathrm{C}$ and a chamber water vapor pressure between 4.5 and 5.5 Torr. Water vapor was allowed to condense on the cooled target to keep it moist while performing ESEM imaging. Liquid water was removed from the top layer, several microns thick, to view the strands of
GF. A gaseous secondary electron detector (GSED) was used to collect the ESEM images of the wet/moist sub sample surface.

\section{Results and discussion}

\subsection{Air cathodes}

Optimizing the efficiency of the cathode is essential to maximizing power output from any MFC. GF electrodes $\left(0.47 \mathrm{~m}^{2} / \mathrm{g}\right)$ were used for this work because of their low density (good flow characteristics through chamber) and high surface area $\left(600 \mathrm{~cm}^{2} / 0.13 \mathrm{~g}\right)$. Previous experiments showed the effectiveness of the mini-MFC design with GF electrodes towards achieving high power densities per volume using ferricyanide as the catholyte (Ringeisen et al., 2006). The reduction of ferricyanide (Eq. (1)) and the reduction of oxygen (Eqs. (2) and (3)) are commonly used as the cathodic reactions in MFCs. However, the use of ferricyanide would be problematic as a catholyte for real-time deployment because it is required in stoichiometric quantities.

$\mathrm{Fe}(\mathrm{CN})_{6}^{3-}+1 \mathrm{e}^{-} \rightarrow \mathrm{Fe}(\mathrm{CN})_{6}^{4-}$,

$E^{\circ}=\sim 430 \mathrm{mV} \quad$ (Roncel et al., 2001)

$\mathrm{O}_{2}+4 \mathrm{e}^{-}+4 \mathrm{H}^{+} \rightarrow 2 \mathrm{H}_{2} \mathrm{O}$

$E^{\circ}=820 \mathrm{mV} \quad($ Sawyer and Williams, 1991)

$\mathrm{O}_{2}+2 \mathrm{e}^{-}+2 \mathrm{H}^{+} \rightarrow \mathrm{H}_{2} \mathrm{O}_{2}$

$E^{\circ}=280 \mathrm{mV} \quad($ Sawyer and Williams, 1991)

Three separate DSP10 mini-MFCs were constructed with Nafion ${ }^{\circledR}-117$ membranes and either oxygen cathodes using uncoated GF or a Pt/C coated GF electrodes in $100 \mathrm{mM}$ phosphate buffer catholyte ( $\mathrm{pH}$ 7.2). These oxygen cathodes were aerated with $0.45 \mu \mathrm{m}$ filtered air bubbled through the buffered salt solution. Results for the ferricyanide experiments using uncoated GF electrodes with a $50 \mathrm{mM} \mathrm{K}{ }_{3} \mathrm{Fe}(\mathrm{CN})_{6}$ catholyte are shown in Fig. 1. For comparison, this figure also shows the maximum power recorded for the bare GF oxygen cathode $(14 \mu \mathrm{W})$ which was $10 \%$ of the maximum power observed for the $\mathrm{Pt} / \mathrm{C}$ cathode $(150 \mu \mathrm{W})$. The bare GF cathode produced only $4 \%$ of the power of a mini-MFC with a ferricyanide catholyte. The

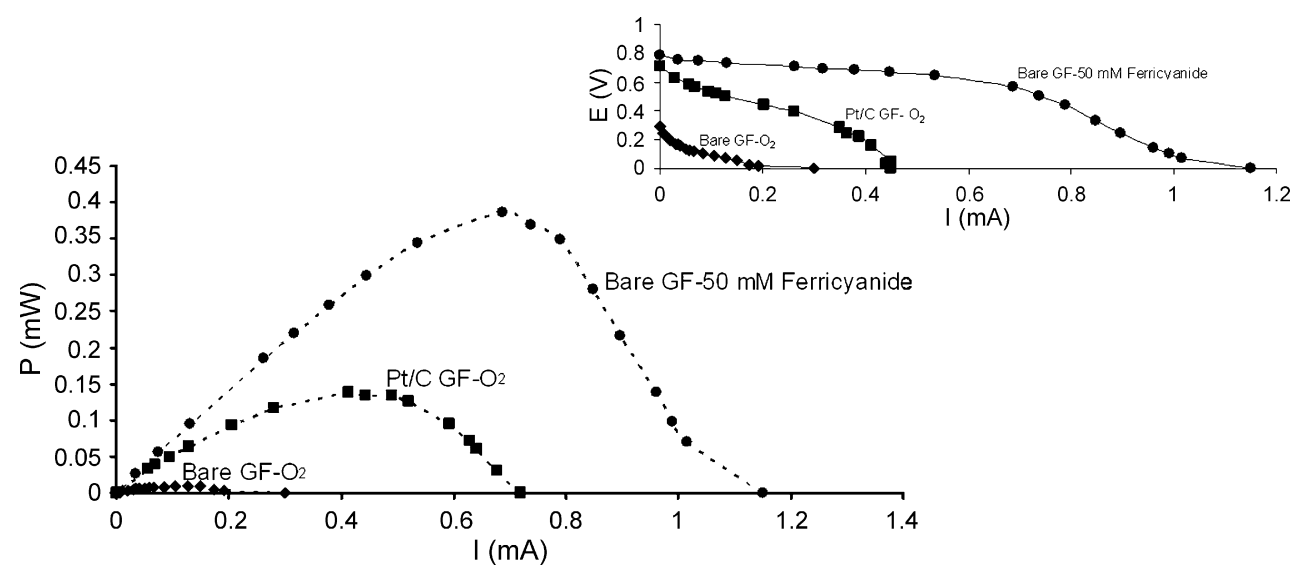

Fig. 1. Comparison between the power and voltage (inset) generated by a mini-MFC with $10^{8}$ cells $/ \mathrm{mL}$ culture DSP10 anodes and selected cathodes. 
power generated within this work using planktonic DSP10 was $400 \mu \mathrm{W}$, slightly lower than previously published mini-MFC results (Ringeisen et al., 2006). This decrease is due to the lower concentration of bacteria in the anode cultures and the reduced temperature under which the mini-MFC was operated $\left(17-20^{\circ} \mathrm{C}\right)$.

The substantial power densities generated when using oxygen cathodes demonstrate the advantages of the short diffusion distances and high surface area-to-chamber volume ratio of the mini-MFC when compared to macroscopic MFC designs. Even when using the bare GF oxygen cathode, the mini-MFC power density (true surface area: $0.23 \mathrm{~mW} / \mathrm{m}^{2}$; cross-sectional surface area: $70 \mathrm{~mW} / \mathrm{m}^{2}$ ) was $>50$ times the maximum power generated from a macroscopic MFC using a pure Shewanella culture as the anolyte and a comparable oxygen cathode (Kim et al., 2002). When incorporating a Pt/C cathode with relatively low (2-5\%) Pt loading, the mini-MFC produced nearly $40 \%$ of the maximum power measured with a ferricyanide catholyte (Fig. 1). The real advantage of using oxygen versus ferricyanide was that the fuel cell with the Pt/C cathode could be operated for $>2$ weeks with only a $10 \%$ drop in power, while the fuel cell with a ferricyanide catholyte had to be replenished at least three times over the same time period. Even though the reduction of ferricyanide generates more power than the reduction of oxygen under these conditions, the use of oxygen is an operational requirement for MFCs deployed in natural settings for long periods of time.

Ferricyanide is an excellent catholyte for the comparison of maximum power values for the wide range of MFCs already published in the literature (Park and Zeikus, 2003; Oh et al., 2004; Pham et al., 2004). The relatively lower power output of oxygen or air catholytes compared to that obtained by ferricyanide reduction is probably due to the slow kinetics of oxygen reduction compared to ferricyanide reduction (Tarasevich et al., 1983). Doping carbon electrodes with platinum catalysts aides in decreasing the overpotential for oxygen reduction as demonstrated in experiments performed over a century ago (Grove, 1839). Subsequent advances in materials for fuel cell development were recently reviewed (Steele and Heinzel, 2001).

The maximum power densities for the mini-MFC are $8.2 \mathrm{~mW} / \mathrm{m}^{2}$ (true surface area) and $420 \mathrm{~W} / \mathrm{m}^{3}$ with a ferricyanide catholyte. Compared to the ferricyanide catholyte (Table 1), the power density decreased by $60 \%$ with the $\mathrm{Pt} / \mathrm{C}$ coated cathode in an oxygen saturated catholyte $\left(2.5 \mathrm{~mW} / \mathrm{m}^{2}, 150 \mathrm{~W} / \mathrm{m}^{3}\right)$ and up to $95 \%$ with a bare GF electrode $\left(0.23 \mathrm{~mW} / \mathrm{m}^{2}, 12 \mathrm{~W} / \mathrm{m}^{3}\right)$.
Our results for the mini-MFC are consistent with the MFC literature in that a $>50 \%$ drop in power is observed when comparing ferricyanide to oxygen reduction cathodes (Oh et al., 2004). Taking into account the low platinum loadings of these $\mathrm{Pt} / \mathrm{C}$ electrodes $(2-4 \%)$ and the use of a pure culture of DSP10, the observed reduction in power density is competitive with other MFC designs. The overall power density per volume of our pure culture device operating with a $\mathrm{Pt} / \mathrm{C}$ cathode is similar to the power density observed from other macroscopic MFCs using mixed cultures. Bacterial consortia are known to enhance power densities by orders of magnitude (maximum for oxygen reduction cathode $=102 \mathrm{~W} / \mathrm{m}^{3}$ (Moon et al., 2006); maximum for ferricyanide cathode $=388 \mathrm{~W} / \mathrm{m}^{3}$ (Rabaey et al., 2003).

Another design that is finding favor in the MFC field is a "membraneless" system that operates without a PEM separator. These single chamber fuel cells are advantageous in that removal of the membrane decreases the overall cost and internal resistance of the fuel cell while increasing the flux of protons to the cathode. For example, a MFC using carbon cloth anodes and carbon paper cathodes produced two times the power of a fuel cell with a PEM membrane $\left(0.49 \mathrm{~W} / \mathrm{m}^{2}, \mathrm{Pt} / \mathrm{C}\right.$ cathode $)$ incorporated into the same design (Cheng et al., 2006). However, the power densities of other single chamber devices are less than those reported for other two chamber designs because of the presence of oxygen at the anode (Jang et al., 2004; Liu and Logan, 2004). Also, single chamber devices suffer from bacterial motility. Biofilms are dynamic, so when a biofilm is formed, eventually some of the bacteria detach and start to divide in the chamber leading to bacterial fouling of the cathode (Cheng et al., 2006). Generally, a smaller two-chamber design with shorter diffusion lengths and a high-surface-area-to-chamber volume ratio exhibits greater power densities to that of larger MFC and single chamber fuel cells.

\subsection{Biofilm formation on graphite felt}

Formation of stable biofilms enable direct electron transfer from metal reducing bacteria to the electrode and could promote the maintenance of certain bacteria in a competitive foreign environment. In order to elucidate the electron transfer mechanism in the mini-MFC system and to move towards a standalone, deployable device, we investigated biofilm growth and power output of the MFCs with DSP10 biofilm-coated anodes. However, predicting conditions and prerequisites for substan-

Table 1

Power densities for mini-MFCs with various cathodes

\begin{tabular}{lclr}
\hline & Power density $\left(\mathrm{W} / \mathrm{m}^{3}\right)$ & $\begin{array}{l}\text { Power density (per true surface area) } \\
\left(\mathrm{mW} / \mathrm{m}^{2}\right)\end{array}$ & $\begin{array}{l}\text { Power density (per device } \\
\text { cross-section })\left(\mathrm{mW} / \mathrm{m}^{2}\right)\end{array}$ \\
\hline Cathode (full DSP10 culture) & 12 & 0.23 & 70 \\
$\quad$ Uncoated GF-O & & 2.5 & 750 \\
Pt/C GF-O 2 & 150 & 8.2 & 2500 \\
$\quad$ Uncoated GF-ferricyanide & 420 & & 160 \\
Cathode (biofilm coated anode) & & 0.52 & 1500 \\
$\quad$ Pt/C GF- $\mathrm{O}_{2}$ & 26 & 4.9 & \\
$\quad$ Uncoated GF-ferricyanide & 250 & & \\
\hline
\end{tabular}




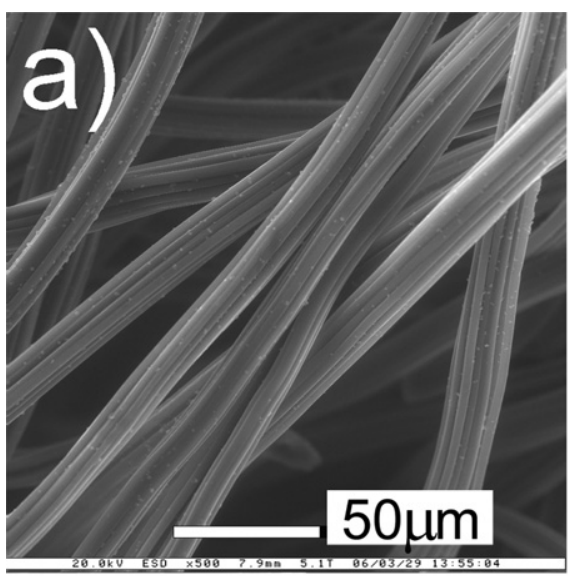

Bare GF

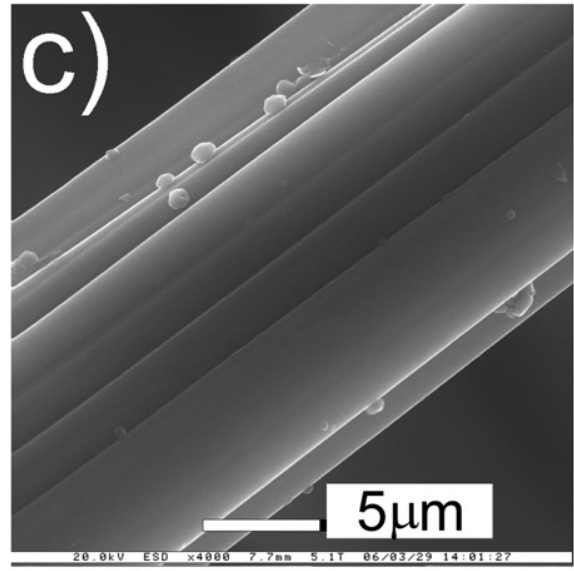

Bare GF

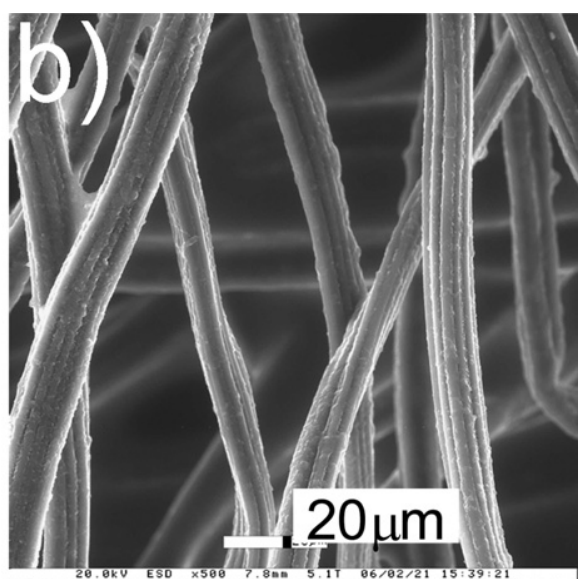

DSP10 Biofilm

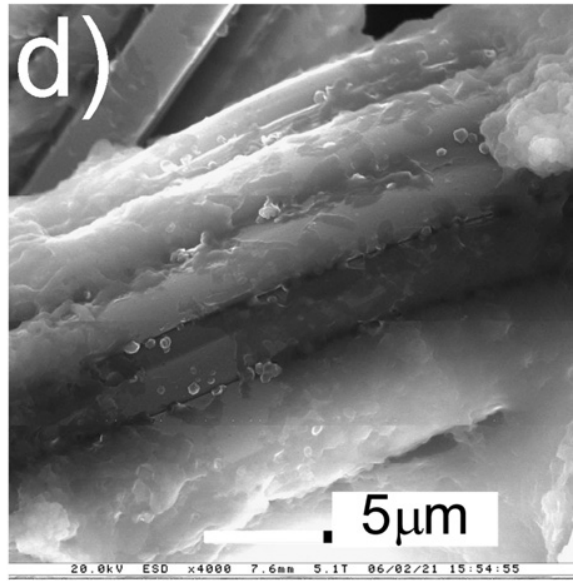

DSP10 Biofilm

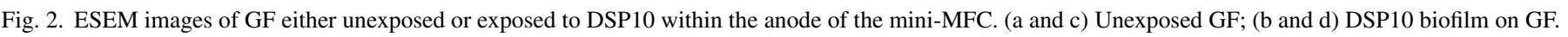

tial biofilm formation on the anode is difficult. A recent review simplifies the components needed for biofilm growth into three basic parts: microbes, glycocalyx (secreted polymer matrix protecting the bacteria on the surface), and a surface (Dunne, 2002). While this description is a gross oversimplification, it illustrates that the range of conditions for biofilm formation is extremely variable and must by optimized for specific bacteria (An and Friedman, 1998).

Fig. 2 shows the ESEM images of bare GF (left) and DSP10 exposed GF (right) after being removed from a fuel cell that was operated for $>2$ weeks (power versus time data shown in Fig. 3). Fig. 2b and d are the first examples of ESEM images for a Shewanella biofilm formed on GF. The biofilm coverage appears dense with variable thickness from slightly below monolayer to multilayer coverage.

For these biofilm experiments, two different cathodes were used; the first used a bare GF cathode with a $50 \mathrm{mM}$ ferricyanide catholyte (Fig. 3) while the second used a Pt/C GF oxygen reduction cathode with a $100 \mathrm{mM}$ phosphate buffer catholyte (supporting information). Mini-MFC experiments were run with an anolyte comprised of $50 \mathrm{~mL} \mathrm{LB}$, inoculated ( $<30 \mathrm{~min}$ ) with a culture $\left(2.5 \mathrm{~mL}\right.$ of a culture containing $10^{8}$ cells $\left./ \mathrm{mL}\right)$ of DSP10 (Fig. 3). Subsequent flushing with and exposure to acellular min- imal media promoted bacterial conditioning of the surface. Over the full 10-day operational period, the anode was exposed to low nutrient conditions and rapidly growing bacterial cultures. Both fuel cells (ferricyanide and oxygen cathodes) were operated for over $300 \mathrm{~h}$ with periodic stimulus with sodium lactate. The initial growth period was monitored by the voltage profile taken across an $1800-\Omega$ load (Fig. 3) over $330 \mathrm{~h}$. The gradual increase in current at the outset can be attributed to the logarithmic increase in bacterial concentration commonly seen after 3 days of growth at $25^{\circ} \mathrm{C}$ for DSP10. The decrease in power after day four is most likely because the concentration of nutrients in the culture could no longer support the culture density. This creates a minimal nutrient state that should stimulate the desired bacterial adhesion to GF. Considering the likelihood that bacteria need to condition a surface prior to bacterial attachment, both rapid cellular division and the minimal nutrient conditions were used to form a substantial biofilm. It was also interesting that $50 \%$ of the power achieved with lactate stimulus was observed with only LB broth and DSP10 during the conditioning phase of the experiment, which shows that Shewanella can use complex substrates other than lactate and fumarate to generate power.

Once this conditioning period was deemed over, the $1800 \Omega$ load was exchanged for the $820 \Omega$ load and the fuel cell anode 


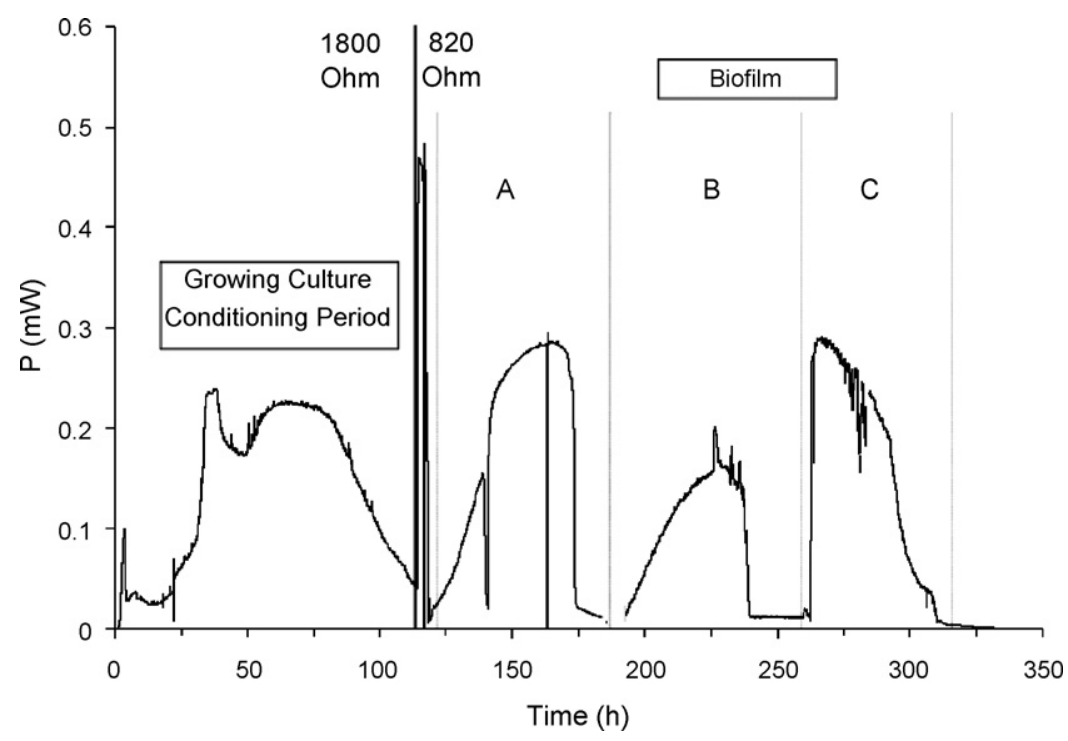

Fig. 3. Lifetime and power characteristics of a mini-MFC with a developing biofilm. (A) Purged full culture with $50 \mathrm{~mL}$ LB followed by $25 \mathrm{~mL}$ minimal media (MM) under a nitrogen atmosphere with $30 \mathrm{mM}$ sodium lactate; (B) purged the turbid culture with $50 \mathrm{~mL}$ LB followed by $25 \mathrm{~mL}$ minimal media (MM) under a nitrogen atmosphere with $15 \mathrm{mM}$ sodium lactate; (C) purged full culture with $50 \mathrm{~mL}$ LB followed by $25 \mathrm{~mL}$ minimal media (MM) under a nitrogen atmosphere with $30 \mathrm{mM}$ sodium lactate. The catholyte was $50 \mathrm{mM} \mathrm{K}{ }_{3} \mathrm{Fe}(\mathrm{CN})_{6}$ in $100 \mathrm{mM}$ phosphate buffer (pH 7.2).

was purged with degassed MM (Myers and Nealson, 1988) containing $10 \mathrm{mM}$ sodium lactate (Fig. 3A). After the culture was removed, the power dropped to below $10 \mu \mathrm{W}$ but gradually increased to $250 \mu \mathrm{W}$ over the next 2 days with an increase in the turbidity of the culture flask. The significant drop in power after $140 \mathrm{~h}$ was due to the depletion of ferricyanide for the cathodic reaction. Refreshing the ferricyanide catholyte returned the power to the anticipated output.

The turbid culture that was being used at the end of section A was removed from the fuel cell system and was replaced with MM containing $15 \mathrm{mM}$ sodium lactate after flushing the system. This amount of lactate resulted in half the power output of the $30 \mathrm{mM}$ lactate addition (A) which suggests that the decrease in overall lactate concentration led to a lower concentration of bacteria in the culture after time period B (Fig. 3B) or slower diffusion of nutrients to the bacteria on the inner portion of the biofilm. The final $50 \mathrm{~h}$ of operation (Fig. 3C) exhibited a different power profile than the lactate additions in sections $\mathrm{A}+\mathrm{B}$. Considering the culture was purged with $\mathrm{MM}$ and $30 \mathrm{mM}$ sodium lactate at the beginning of section $\mathrm{C}$, the response to lactate was similar to the latter half of section A where the effect of lactate on a turbid culture was shown. The immediate response to lactate in $\mathrm{C}$ suggests that a substantial biofilm was formed after $250 \mathrm{~h}$ of operation. These results demonstrate that the initial biofilm could be manipulated to provide $>300 \mathrm{~h}$ of electricity with no observable drop in output power.

\subsection{Power output from a biofilm-enhanced mini-MFC}

The maximum power recorded after the addition of lactate following the anode enrichment phase $(500 \mu \mathrm{W}$ across an $820 \Omega$ resistor) was used to compare the power without a full DSP10 culture as the anolyte (biofilm only, Fig. 4). The fuel cell operating with just a biofilm consists of far fewer cells per milliliter resulting in a significantly higher concentration of oxygen in the anode chamber (Fig. 4) and a decrease in power (closed squares, dashed line). The effects of oxygen in the anode chamber for the mini-MFC output were reported recently, with rigorous aeration being necessary to observe any detrimental effect on output power. MFCs under aerobic conditions generated lower power with outputs reduced by $40 \%$ (Ringeisen et al., in press) to $100 \%$ (no power generated) (Kim et al., 2002) compared to a strictly anaerobic anode chamber. Similar to previous observations for full culture mini-MFC experiments, the presence of oxygen in the anode chamber of the biofilm-enhanced experiment reduced the power output by half from the fuel cell operated under a nitrogen atmosphere (Fig. 4; closed triangles, dashed line).

To ensure that we measured the power generated from the biofilm alone without planktonic bacteria, the power measurements over a range of external loads for the biofilm mini-MFC were taken no longer than one hour after the anode chamber was purged with degassed acellular MM + lactate. The power densities (Table 1) for the mini-MFC with a biofilm formed on the anode and a ferricyanide catholyte were $250 \mathrm{~W} / \mathrm{m}^{3}$ and $4.9 \mathrm{~mW} / \mathrm{m}^{2}$ (true surface area) (Fig. 4). The maximum power was $300 \mu \mathrm{W}$ with a $470 \Omega$ resistor. When a Pt/C oxygen reduction cathode was used, the power densities were reduced to $26 \mathrm{~W} / \mathrm{m}^{3}$ and $0.52 \mathrm{~mW} / \mathrm{m}^{2}$ (Fig. 5) with a maximum power of $32 \mu \mathrm{W}$ across an $820-\Omega$ resistor. The "full culture" maximum power in Fig. $5(70 \mu \mathrm{W})$ was $50 \%$ less than the power reported in Fig. 1 using the same Pt/C cathode. The discrepancy in power was due to the lower concentration of bacteria in the fuel cell used for biofilm development as opposed to the $10^{8}$ cells $/ \mathrm{mL}$ culture used to compare the power generated for each cathode under similar conditions.

Only one other paper reported the power produced from a biofilm only (Bond and Lovley, 2003). The G. sulfurreducens device used block graphite electrodes and produced a power 


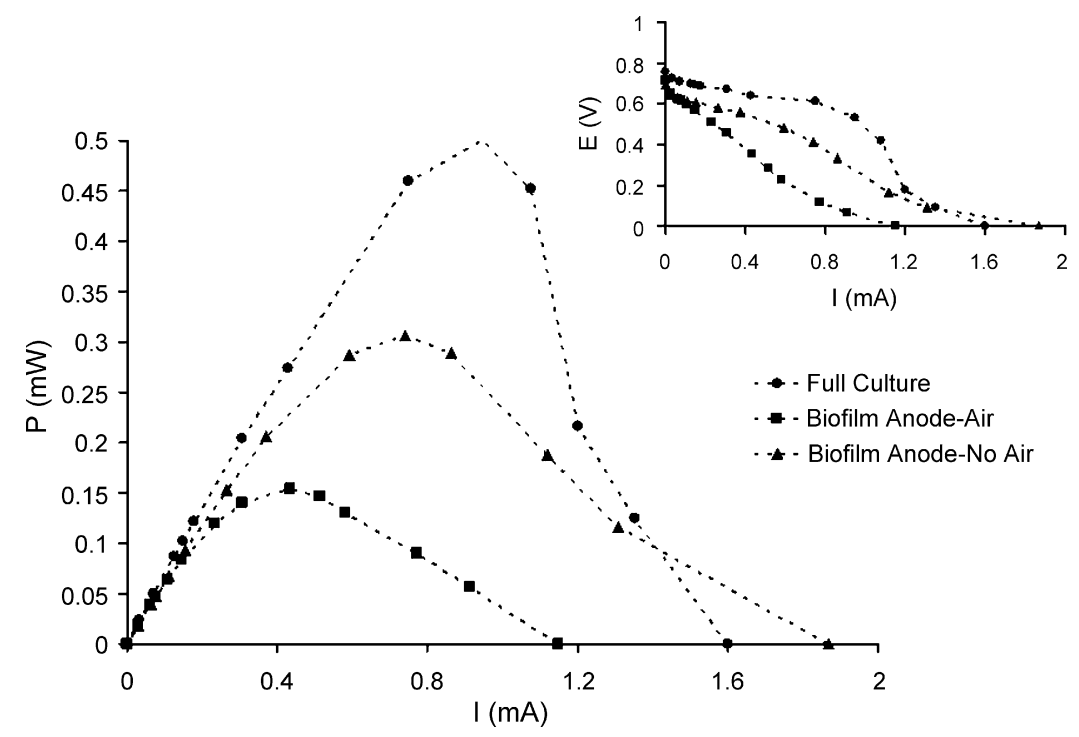

Fig. 4. Power and voltage (inset) vs. current for a mini-MFC with biofilm formation and a ferricyanide catholyte.

density per volume of $0.42 \mathrm{~W} / \mathrm{m}^{3}$ with an air cathode. This power is similar to the power density of the mini-MFC after accounting for the use of a Pt/C cathode rather than a bare GF electrode (estimate for power density using bare GF: $2 \mathrm{~W} / \mathrm{m}^{3}$ ). However, their MFC was not optimized for generating maximum power densities. If the power measurement for the mini-MFC was taken one hour after purging the system, only $50 \%$ of the power was observed, suggesting that the subsequent increase in power over the next 2 days (up to $100 \%$ ) was due to the increase of planktonic bacteria in the system.

Bacterial attachment to surfaces is influenced by nutrient concentration-a decrease in nutrients leading to an increase in bacterial attachment (Dunne, 2002). Most MFCs reported in the literature describe an initial "enrichment" phase of the anode that can range up to 3 years (Gil et al., 2003). Biofilm formation is usually observed by scanning electron microscopy (SEM) or a gradual increase in current observed from a MFC itself. Unlike the experiments described herein, our previous work used $10^{8}$ cells/mL DSP10 cultures during the entire time of operation of the mini-MFC with only partial biofilm formation observed (Ringeisen et al., 2006). These previous experiments were performed under the assumption that significant bacterial attachment would occur on the anode regardless of the cell concentration or the stage of growth of the culture (lag phase, logarithmic growth, stationary phase, or decline). However, if a fuel cell is exposed to a bacterial culture during the stationary phase (after 4 days the DSP10 culture reaches this phase), the bacterial population is predisposed toward being planktonic, as no advantage is gained by adhering to a surface in large numbers in the presence of nutrients. As a result, only partial biofilm formation was observed by ESEM on the anode using planktonic cultures of DSP10 after 2 weeks. This partial bacterial coverage of the anode resulted in very low power output ( $10 \%$ of the power observed compared to the full culture response) after the anode chamber and input/output tubes were purged with $100 \mathrm{mM}$ phosphate buffer and lactate with a $50 \mathrm{mM}$ ferricyanide cathode.

The constant flux between planktonic bacteria and bacteria in biofilms is clearly seen from two of the traces in Fig. 5 (Pt/C

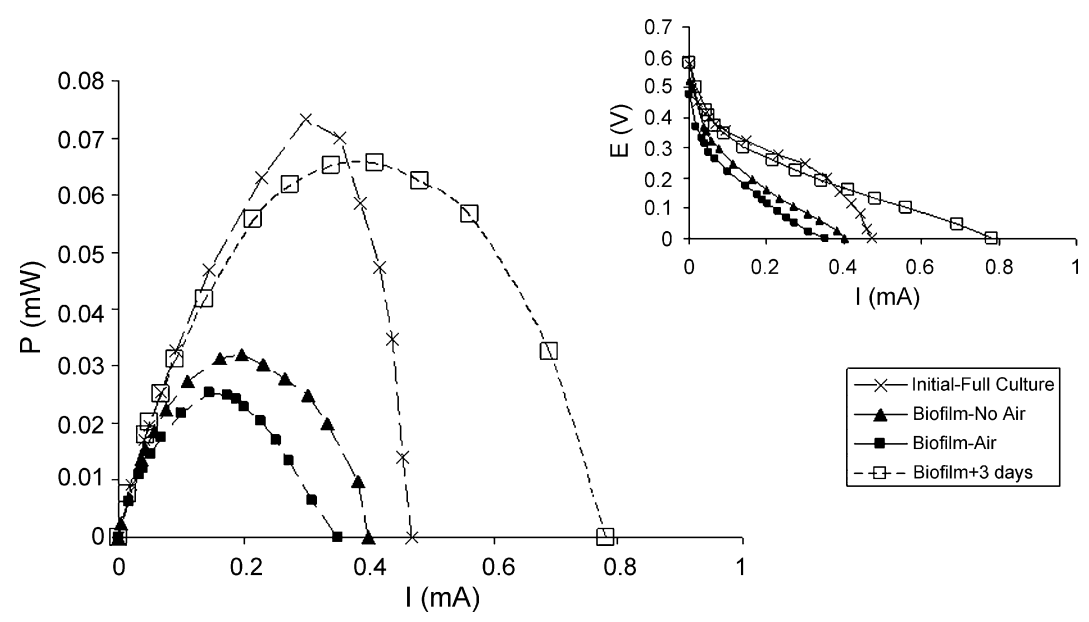

Fig. 5. Power and voltage (inset) vs. current for a mini-MFC with biofilm formation and a Pt/C GF oxygen cathode. 
(a)

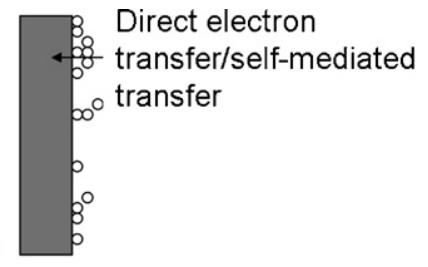

(b)

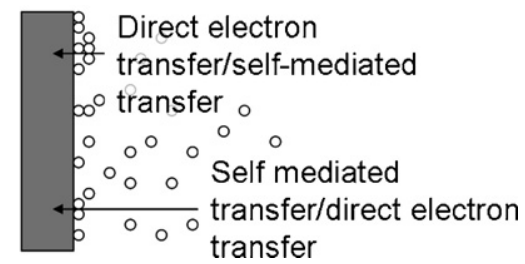

Fig. 6. Schematic representation of the mechanisms for electron transfer from Shewanella as either a (a) biofilm attached to the anode or (b) biofilm with planktonic bacteria present.

cathode). The power produced from the biofilm immediately after being purged and degassed (biofilm-no air) was $35 \mu \mathrm{W}$. But after the fuel cell was run for 3 days in MM plus sodium lactate, the culture flask was noticeably turbid with a maximum power very close $(65 \mu \mathrm{W})$ to the power of a full DSP10 culture $(74 \mu \mathrm{W})$ (Fig. 3). Given the tendency of bacteria in biofilms to detach from the surface, the $30 \mu \mathrm{W}$ difference between the biofilm alone and the turbid culture was most likely generated from solutionphase DSP10 and/or excreted mediators (self-mediation) from the planktonic cells. These results suggest that the biofilm on the anode does not cover the entire surface of the electrode. So, as the bacterial concentration increases in the culture, the power generated from the fuel cell increases because more of the electrode surface is being utilized (Fig. 6). Biofilm formation in MFCs will be advantageous for a real world system by predisposing the anode chamber with the desired bacteria prior to deployment in a natural environment.

\section{Conclusions}

The mini-MFC design was modified with oxygen cathodes that are directly applicable to environmental deployment. There was a $>50 \%$ power loss when switching from a $50 \mathrm{mM}$ ferricyanide catholyte to a platinum on vulcanized carbon oxygen reduction cathode. Biofilms of DSP10 were formed on graphite felt after 5 days under reduced nutrient conditions at $25^{\circ} \mathrm{C}$. The power generated with the biofilm-enhanced anode was $60 \%$ of that generated with the planktonic culture. The output power increased during the operation of the fuel cell as the solution-phase bacterial concentration increased in the reservoir flask/culture. The power densities per unit volume produced by the DSP10-only biofilm mini-MFC are comparable to the largest reported for MFCs using planktonic mixed cultures with either ferricyanide or oxygen reduction cathodes.

\section{Acknowledgement}

This work was funded by Office of Naval Research (NRL 6.2 Program Element Number 62123N).

\section{Appendix A. Supplementary data}

Supplementary data associated with this article can be found, in the online version, at doi:10.1016/j.bios.2006.07.027.

\section{References}

An, Y.H., Friedman, R.J., 1998. J. Biomed. Mater. Res. 43 (3), 338-348. Angenent, L.T., Karim, K., et al., 2004. Trends Biotechnol. 22 (9), 477-485. Bond, D.R., Lovley, D.R., 2003. Appl. Environ. Microbiol. 69 (3), 1548-1555. Bullen, R.A., Arnot, T.C., et al., 2006. Biosens. Bioelectron. 21, 2015-2045.

Cheng, S., Liu, H., et al., 2006. Electrochem. Commun. 8 (3), 489-494.

Chiao, M., Lam, K.B., et al., 2003. Proceedings-IEEE Annual International Conference on Micro Electro Mechanical Systems 16th, Kyoto, Japan, January 19-23, pp. 383-386.

Dunne Jr., W.M., 2002. Clin. Microbiol. Rev. 15 (2), 155-166.

Gil, G.-C., Chang, I.-S., et al., 2003. Biosens. Bioelectron. 18 (4), 327-334.

Grove, W.R., 1839. Philos. Mag. Ser. 3 (14), 127-130.

Hernandez, M.E., Newman, D.K., 2001 . Cell. Mol. Life Sci. 58 (11), 1562-1571. Jang, J.K., Pham, T.H., et al., 2004. Process Biochem. 39 (8), 1007-1012.

Kim, H.J., Park, H.S., et al., 2002. Enzyme Microb. Technol. 30 (2), 145-152.

Liu, H., Logan, B.E., 2004. Environ. Sci. Technol. 38 (14), 4040-4046.

Lowy, D.A., Tender, L.M., et al., 2006. Biosens. Bioelectron. 21 (11), 2058-2063.

Moon, H., Chang, I.S., et al., 2006. Bioresour. Technol. 97 (4), 621-627.

Myers, C.R., Nealson, K.H., 1988. Science (Washington, DC) 240 (4857), 1319-1321.

Oh, S., Min, B., et al., 2004. Environ. Sci. Technol. 38 (18), 4900-4904.

Park, D.H., Zeikus, J.G., 2003. Biotechnol. Bioeng. 81 (3), 348-355.

Pham, T.H., Jang, J.K., et al., 2004. J. Microbiol. Biotechnol. 14 (2), 324-329.

Rabaey, K., Lissens, G., et al., 2003. Biotechnol. Lett. 25 (18), 1531-1535.

Rabaey, K., Verstraete, W., 2005. Trends Biotechnol. 23 (6), 291-298.

Reimers, C.E., Tender, L.M., et al., 2001. Environ. Sci. Technol. 35 (1), 192-195.

Ringeisen, B.R., Henderson, E., et al., 2006. Environ. Sci. Technol. 40 (8), 2629-2634.

Ringeisen, B.R., Ray, R., et al. J. Power Sources, 2006, in press.

Roncel, M., Ortega, J.M., et al., 2001. Eur. J. Biochem. 268 (18), 4961-4968.

Sawyer, D.T., Williams, R.J.P., 1991. Oxygen Chemistry (International Series of Monographs on Chemistry). Oxford University Press.

Schröder, U., Niessen, J., et al., 2003. Angew Chem. Int. Ed. Engl. 42 (25), 2880-2883.

Steele, B.C.H., Heinzel, A., 2001. Nature (London) 414 (6861), 345-352.

Tarasevich, M.R., Sadkowski, A., et al., 1983. Compr. Treatise Electrochem. 7, 301-398.

Tender, L.M., Reimers, C.E., et al., 2002. Nat. Biotechnol. 20 (8), 821-825. 